\title{
Design of a Novel Method for the Spatial Distribution of Cells within a Porous Scaffold for Tissue Engineering Applications
}

\author{
Revathy Subramanian, Rudra Bhowmick and Heather Gappa-Fahlenkamp* \\ School of Chemical Engineering, Oklahoma State University, Stillwater, OK 74078, USA
}

\begin{abstract}
Tissue engineering is rapidly progressing to provide complex, three-dimensional (3D) representations of human tissues that can be used for tissue replacement and/or to study tissue systems. Tissue engineering includes the addition of cells within 3D scaffolds, along with bioactive components, sometimes within a bioreactor. A major challenge in developing many tissue-engineered models is the ability to evenly distribute cells throughout a porous scaffold, in order to achieve good cell viability and growth. In this study, we created a 3D collagen-chitosan scaffold with specific properties to aid in seeding cells within the entire volume and investigated a dynamic method to seed cells within such scaffold. Based on the requirements for cell seeding, the scaffolds were less than $500 \mu \mathrm{m}$ thick, had pore sizes greater than $50 \mu \mathrm{m}$ and had a porosity of $50 \%$ or greater. Fibroblasts were used as model cells for this seeding method. To seed fibroblasts within the scaffold, we varied two design parameters: concentration of the collagen seeding solution and the centrifugal force used for cell seeding. We ranked the seeding efficiency, cell proliferation and distribution in order to choose the ideal cell seeding method. Results showed that seeding with a higher concentration $(2 \mathrm{mg} / \mathrm{ml})$ of collagen seeding solution and a lower centrifugation speed $(259 \times \mathrm{g})$ was the optimal seeding method, resulting in $84 \%$ increase in cell proliferation and a more uniform cell distribution throughout the scaffold. Results from this study can be applied for seeding a variety of cell populations within porous scaffolds for tissue engineering applications.
\end{abstract}

Keywords: Scaffold; Tissue engineering; Cell seeding; Cell distribution

\section{Introduction}

Engineering human tissue requires sophisticated culture techniques, where the in vitro conditions recapitulates the in vivo physiology. The traditional monolayer (two-dimensional, 2D) cultures fail to capture the in vivo cell responses, possibly due to the lack of an added dimension for three-dimensional (3D) spatial cues [1]. Two-dimensional cultures are also prone to external perturbations, and may result in dedifferentiation of cells [2]. On the other hand, 3D cultures, where cells are cultured within scaffolds or as aggregates, establish intercellular "tissue-like" networks, and behave in a more in vivo-like manner $[1,3]$. Our research focus is to develop $3 \mathrm{D}$ engineered models of human tissue that can be used as a potential alternative to in vivo studies. As a first step in this regard, the goal of this study was to develop a new, dynamic cell seeding method for seeding cells throughout the volume of a $3 \mathrm{D}$, porous scaffold.

Three-dimensional scaffolds have been widely used to study cell attachment, proliferation and migration [4]. When cultured within scaffolds, cells produce extracellular matrix (ECM) molecules and eventually form $3 \mathrm{D}$ structures that resemble native tissues, aided by the ability of the scaffolds as a carrier for biochemical signals [5]. Ideal scaffolds should be biocompatible, with a porosity to allow for the transport of oxygen and nutrients to the cells and for easy waste removal [6]. Natural materials such as chitosan and collagen demonstrate selective cell adhesion and other physiological qualities and therefore have been used to make scaffolds for a variety of cell types $[7,8]$. The chitosan-collagen combination also improves the mechanical properties of the scaffold and is one of the most widely used materials for a variety of scaffolds, such as for skin and cartilage reconstruction [9].

Porosity with high inter-pore connectivity is an important criterion in scaffold design, as it allows for better cell proliferation, differentiation and migration. Porosity also allows for better mass transport of metabolites. One of the techniques used to create scaffolds with continuous, uninterrupted pore structure is the freeze drying method or lyophilization. In this method, the polymer solution is frozen to form crystals followed by sublimation of solvent crystals and has been used with natural polymers such as collagen [10]. The major advantage of lyophilization is that it does not require toxic solvents, and is therefore a less hazardous fabrication process. The average pore size can be controlled by varying the initial freezing temperature, $\mathrm{pH}$ and the freezing rate. However, with this method, it can be difficult to control the pore size distribution, pore geometry and thickness of the scaffold.

The ideal cell seeding method must result in a high seeding efficiency, cells evenly distributed throughout the entire volume of the scaffold, good cell viability, and functional cells that are able to proliferate. It is difficult to seed cells within a $3 \mathrm{D}$ porous scaffold, as the cells need to traverse the tortuous pore network of the scaffold in order to be uniformly distributed. Cell seeding for 3D cultures using centrifugal seeding has been very effective in this regard $[11,12]$. Ng et al. investigated the effects of centrifugal force and centrifugation time on cell seeding within polyethylene terephthalate (PET) matrices and found that high centrifugal force led to high seeding efficiency and cellular distribution without compromising cell viability [12]. However, as stated in the paper, unless the cells were bound to the fiber in the matrix, they were not retained. Still lacking is a way to distribute cells within the total void volume of a $3 \mathrm{D}$ matrix, while retaining the cells throughout.

The aim of this study was to develop a new, dynamic method for optimum cell seeding within a $3 \mathrm{D}$, porous scaffold, as a first step to create

*Corresponding author: Heather Gappa-Fahlenkamp, School of Chemical Engineering, Oklahoma State University, Stillwater, OK 74078, USA, Tel: 405-7445280; E-mail: Heather.Fahlenkamp@okstate.edu

Received April 09, 2017; Accepted May 12, 2017; Published May 31, 2017

Citation: Subramanian R, Bhowmick R, Gappa-Fahlenkamp H (2017) Design of a Novel Method for the Spatial Distribution of Cells within a Porous Scaffold for Tissue Engineering Applications. J Tissue Sci Eng 8: 201. doi: 10.4172/21577552.1000201

Copyright: @ 2017 Subramanian R, et al. This is an open-access article distributed under the terms of the Creative Commons Attribution License, which permits unrestricted use, distribution, and reproduction in any medium, provided the original author and source are credited. 
3D tissue-engineered models. We achieved this aim by first creating a porous, 3D collagen-chitosan scaffold using a two-stage lyophilization process with intermediate chemical crosslinking that met the design considerations. Next, using fibroblasts as a model cell population, we developed and validated our dynamic method of cell seeding within the $3 \mathrm{D}$ scaffold, using a collagen cell seeding solution and centrifugal force. Adding the cells to the scaffold in a collagen solution protects them from the centrifugal force during seeding, and when the collagen solution gels, it traps the cells throughout the scaffold. Effects of centrifugal force and collagen concentration on the distribution and proliferation of the cells within the scaffold was investigated in order to determine the seeding efficiency of this system.

\section{Materials and Methods}

\section{Scaffold materials}

Chitosan chloride (75-90\% de-acetylation, 150,000-400,000 g/ mol) was donated by FMC BioPolymer (Philadelphia, PA) and Type I collagen (PureCol, $3.1 \mathrm{mg} / \mathrm{ml}$ solution) was purchased from Advanced BioMatrix (San Diego, CA). Permeable cell culture inserts (24-well, 8 $\mu \mathrm{m}$ pore size) and 24-well cell culture plates were from Fisher Scientific (Franklin Lakes, NJ). Sodium tripolyphosphate (technical grade) was purchased from Sigma Aldrich (St. Louis, MO).

\section{Scaffold preparation}

Solutions of collagen and chitosan at varying concentrations (Table 1) were incubated overnight at $37^{\circ} \mathrm{C}$ and mixed at $100 \mathrm{rpm}$ in a RotoMix (type 50800, Thermolyne). One hundred microliters of this solution was pipetted onto permeable membrane inserts, while taking care to avoid bubble formation. Samples were incubated for $2 \mathrm{~h}$ at $-20^{\circ} \mathrm{C}$, followed by lyophilization for $10 \mathrm{~h}$. Lyophilized samples were chemically cross-linked by adding $500 \mu \mathrm{l}$ of $10 \%$ sodium tripolyphosphate (TPP, Sigma-Aldrich, St. Louis, MO) at room temperature. After two hours, the TPP was replaced with $1 \mathrm{ml}$ ultrapure water and incubated overnight at room temperature. Excess water was removed; scaffolds were rinsed three times and frozen at $-20^{\circ} \mathrm{C}$. Scaffolds were lyophilized for $10 \mathrm{~h}$ and stored at room temperature until ready for use. The scaffolds completely covered the surface of the permeable cell culture insert; therefore, the diameter of all the scaffolds was held constant at $6.5 \mathrm{~mm}$.

\section{Scaffold characterization}

Pore size and thickness: The effect of varying the final concentrations of collagen and chitosan in the scaffold on its properties, such as pore size, porosity and thickness was studied. The pore size and thickness of the scaffolds were determined by scanning electron microscopy (SEM). Dried scaffolds were detached from the underlying membrane and mounted on the surface of aluminum stubs. The stubs were sputter

\begin{tabular}{|c|c|c|c|c|c|}
\hline $\begin{array}{c}\text { Scaffold } \\
\text { No. }\end{array}$ & $\begin{array}{c}\text { No. of } \\
\text { Parts } \\
\text { Water }\end{array}$ & $\begin{array}{c}\text { No. of } \\
\text { Parts } \\
\text { Collagen }^{\boldsymbol{b}}\end{array}$ & $\begin{array}{c}\text { No. of Parts } \\
\text { Chitosan } \\
\text { (mg) }\end{array}$ & $\begin{array}{c}\text { Final Collagen } \\
\text { Concentration } \\
\text { (mg/ml) }\end{array}$ & $\begin{array}{c}\text { Final Chitosan } \\
\text { Concentration } \\
\text { (mg/ml) }\end{array}$ \\
\hline 1 & 5 & 1 & 10 & 0.5 & 8.33 \\
\hline 2 & 4 & 2 & 20 & 1.0 & 16.67 \\
\hline 3 & 3 & 3 & 30 & 1.5 & 25.00 \\
\hline 4 & 2 & 4 & 40 & 2.0 & 33.33 \\
\hline 5 & 1 & 5 & 50 & 2.5 & 41.67 \\
\hline 6 & 0 & 6 & 60 & 3.0 & 50.00 \\
\hline
\end{tabular}

Table 1: Varying concentrations of collagen and chitosan used to create the scaffolds. coated with gold and analyzed with SEM (JOEL JSM 6360, Tokyo, Japan). The morphology and pore size were captured at $15 \mathrm{kV}$ with $70 \mathrm{x}$ magnification. Images were analyzed with ImageJ software to determine the pore size and thickness of the scaffolds.

Porosity and swelling studies: Based on the results of the pore size and thickness of the scaffolds, the porosity and swelling ratio was determined for Scaffold 4. To determine the porosity, three sections were cut from the paraffin-embedded scaffold and examined at 40x magnification with a light microscope. Pore area was measured by using ImageJ software, and porosity was measured using Eqn. 1.

$$
\text { porosity }=\frac{\text { sum of pore area }}{\text { Area of scaf fold }} \times 100
$$

To study the swelling capacity of the scaffold, its initial dry weight (initial weight) and then its weight after being placed in $500 \mu \mathrm{l}$ Medium 199 (M199, Invitrogen, Carlsbad, CA) for $1 \mathrm{~h}$ at $37^{\circ} \mathrm{C}$ (final weight) were measured. Excess liquid was removed by blotting the scaffolds prior to weighing it. Swelling capacity was calculated using Eqn. 2.

$$
\text { Swelling capacity }=\frac{\text { Final weight }- \text { intial weight }}{\text { Intial weight }}
$$

\section{Cells and culture media}

Normal human dermal fibroblasts (PromoCell, Heidelberg, Germany) were cultured in M199 (Invitrogen, Carlsbad, CA) supplemented with $5.96 \mathrm{mg} / \mathrm{ml}$ HEPES (Stemcell Technologies, Cambridge, MA), $2.2 \mathrm{mg} / \mathrm{ml}$ sodium bicarbonate (Merck KGaA, Darmstadt, Germany) and $1 \%$ penicillin-streptomycin-glutamine (Thermo Fisher Scientific, Waltham, MA). Cells were grown at $37^{\circ} \mathrm{C}$ in $5 \% \mathrm{CO}_{2}$ in human fibronectin (Alfa Aesar, Ward Hill, MA) coated flasks. Media was changed every $48 \mathrm{~h}$. At $90 \%$ confluence in the flasks, fibroblasts were removed by trypsin (Stemcell Technologies) and seeded on scaffolds. When required, cells were fluorescently labeled with CellTracker Red (Invitrogen), as per manufacturer's instructions. Cells were counted using a hemocytometer.

\section{Cell seeding with collagen solution and centrifugation}

Cells were seeded in a collagen solution prepared with 8 parts of a 1 or $2 \mathrm{mg} / \mathrm{ml}$ collagen, 5 parts of $10 \mathrm{X} \mathrm{M} 199,0.5$ parts of $0.1 \mathrm{~N}$ $\mathrm{NaOH}$ (VWR, West Chester, PA) and 0.5 parts of DPBS (Invitrogen). Fibroblasts were suspended at 1.4 million per $\mathrm{ml}$ of collagen seeding solution. Prior to seeding with cells, scaffolds were UV-sterilized. $1 \mathrm{ml}$ of the collagen-fibroblast suspension was added on top of the scaffolds and centrifuged for $20 \mathrm{~min}$ at $4^{\circ} \mathrm{C}$, either at $1200 \mathrm{rpm}(259 \times \mathrm{g})$ or at $2200 \mathrm{rpm}(840 \times \mathrm{g})$. The seeded scaffolds were incubated at $37^{\circ} \mathrm{C}, 5 \%$ $\mathrm{CO}_{2}$ for $45 \mathrm{~min}$ for the collagen to gel and entrap the fibroblasts within the scaffold. Following this step, the samples were placed in a 24-well culture plate and $650 \mu \mathrm{l}$ and $100 \mu \mathrm{l}$ of complete media was added to the lower and upper compartments, respectively. The scaffolds were observed at $24 \mathrm{~h}$ by microscopy for cell attachment.

Seeding Methods to study the effect of collagen concentration and centrifugal force on cell attachment, proliferation and distribution is shown in Table 2. The following factors were held constant for all methods: concentration of seeded cells (1.4 million cells $/ \mathrm{ml})$, collagen gelation conditions $\left(45 \mathrm{~min}, 37^{\circ} \mathrm{C}, 5 \% \mathrm{CO}_{2}\right)$ and temperature and time of centrifugation $\left(4^{\circ} \mathrm{C}\right.$ and $20 \mathrm{~min}$, respectively). Cells seeded on the top of a scaffold without collagen or centrifugation was taken as Seeding Method 0. Prior to seeding, cells were labeled with CellTracker Red. Cell distribution within the scaffolds was determined by microscopy 
Citation: Subramanian R, Bhowmick R, Gappa-Fahlenkamp H (2017) Design of a Novel Method for the Spatial Distribution of Cells within a Porous Scaffold for Tissue Engineering Applications. J Tissue Sci Eng 8: 201. doi: 10.4172/2157-7552.1000201

Page 3 of 8

at 24 and $72 \mathrm{~h}$ post-seeding to measure initial cell seeding and cell proliferation, respectively.

\section{Distribution of cells within the scaffold}

The spatial distribution of cells within the scaffolds (in the Z-axis as well as in the XY plane) was measured at 24 and $72 \mathrm{~h}$ post-seeding. For this, scaffolds seeded with CellTracker Red labeled cells were fixed with $4 \%$ formaldehyde and sectioned along the thickness using a microtome. Sections were counter stained with DAPI. Samples at the top, middle, and bottom of each scaffold were analyzed by fluorescent microscopy. Images were captured at 200x and analyzed using ImageJ software.

\section{Results and Discussion}

\section{Scaffold optimization}

Scaffolds were characterized using the Tissue Engineered Medical Products Standards (TEMPS) guidelines F2603-06 and F245010, developed by the American Society for Testing and Materials International (ASTM). The following criteria for the scaffolds were

\begin{tabular}{|c|c|c|}
\hline Seeding Method & $\begin{array}{c}\text { Collagen Concentration } \\
(\mathbf{m g} / \mathbf{m l})\end{array}$ & $\begin{array}{c}\text { Centrifugation Speed } \\
\text { (rpm) }\end{array}$ \\
\hline 0 & 0 & 0 \\
\hline 1 & 0 & $1200(259 \times \mathrm{g})$ \\
\hline 2 & 1 & $1200(259 \times \mathrm{g})$ \\
\hline 3 & 2 & $1200(259 \times \mathrm{g})$ \\
\hline 4 & 0 & $2200(840 \times \mathrm{g})$ \\
\hline 5 & 1 & $2200(840 \times \mathrm{g})$ \\
\hline 6 & 2 & $2200(840 \times \mathrm{g})$ \\
\hline
\end{tabular}

Table 2: A two-factor and two-level factorial design to investigate the effect of collagen concentration and centrifugal force on cell growth and distribution within the scaffold. selected based on the design considerations for our cell seeding method: (a) Thickness less than $500 \mu \mathrm{m}$ [13]; (b) Pore size greater than $50 \mu \mathrm{m}$; (c) Porosity greater than $50 \%[12,14]$.

Several factors such as viscosity, concentration of chitosan, and temperature of the solution influences scaffold preparation. Researchers have studied the effect of temperature on chitosan solutions to show that the intrinsic viscosity of chitosan decreased with increasing temperature [15]. Similar behavior was noticed in chitosan solutions in water [16]. Therefore, to keep the viscosity of the collagen-chitosan solution low, we maintained the solution at a constant temperature of $37^{\circ} \mathrm{C}$. Our scaffolds were made with varying concentrations of chitosan and collagen and the viscosity of solutions was noted based on their ease of transfer using a standard pipette. We observed that the viscosity increased with chitosan concentrations greater than $25 \mathrm{mg} / \mathrm{ml}$ (Scaffold 3 , Table 1). This was in agreement with earlier studies, which showed that chitosan exhibits Newtonian behavior at lower concentrations and non-Newtonian behavior at concentrations greater than $15 \mathrm{mg} / \mathrm{ml}$ and up to $50 \mathrm{mg} / \mathrm{ml}$ [17].

Pore size and thickness: We characterized scaffolds for their pore size and thickness using SEM, as shown in Figure 1A, at 70x magnification. Scaffolds with a collagen concentration of less than $2 \mathrm{mg} /$ $\mathrm{ml}$ (Scaffolds 1-3) were brittle and prone to damage, even with gentle handling. SEM images of Scaffold 5 (Figure 1A) showed the surface of the scaffold with very few pores; therefore, this scaffold was not characterized further. For the remaining scaffolds, SEM observations (Figure 1A) demonstrated that the pores were elliptical and the best fitting ellipse was used to measure the major and minor pore size of the scaffolds. Thickness of these scaffolds varied from 360 to $1200 \mu \mathrm{m}$ (Figure 1B). Figure 1C shows the average pore size of scaffolds. The mean pore size of the scaffolds increased with a decrease in collagen
A
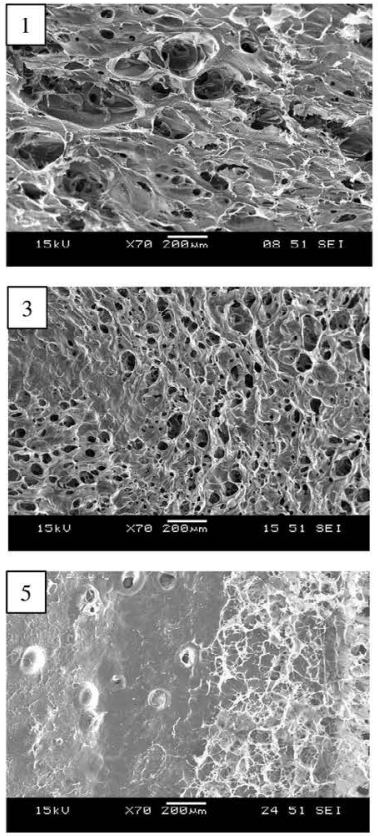
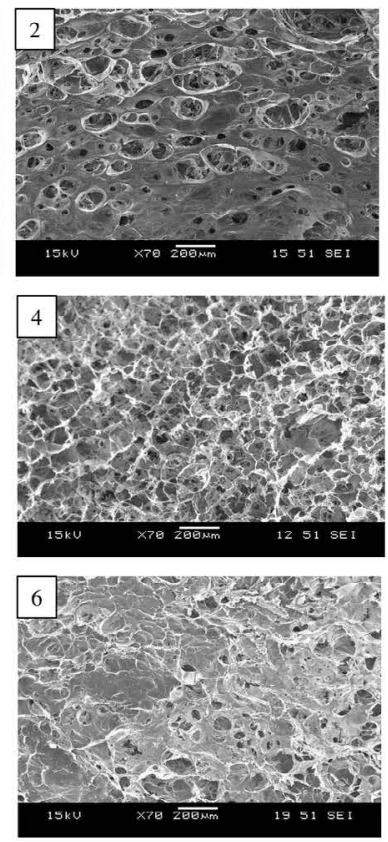

B

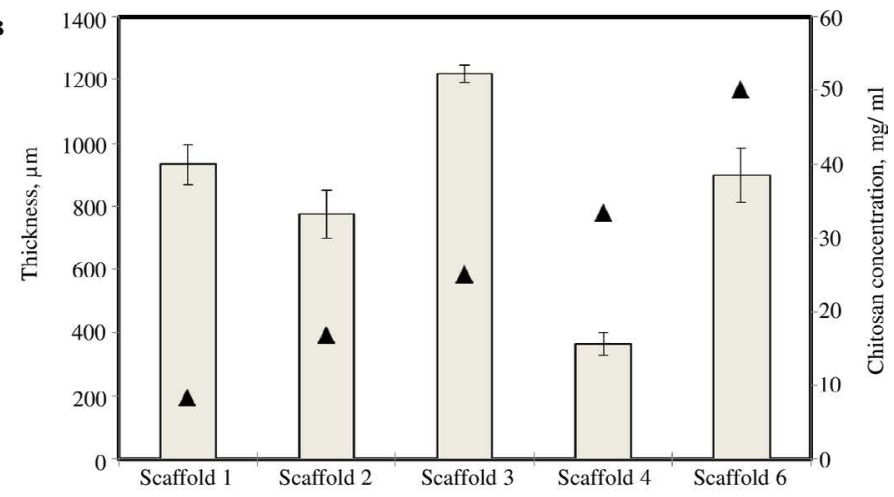

C

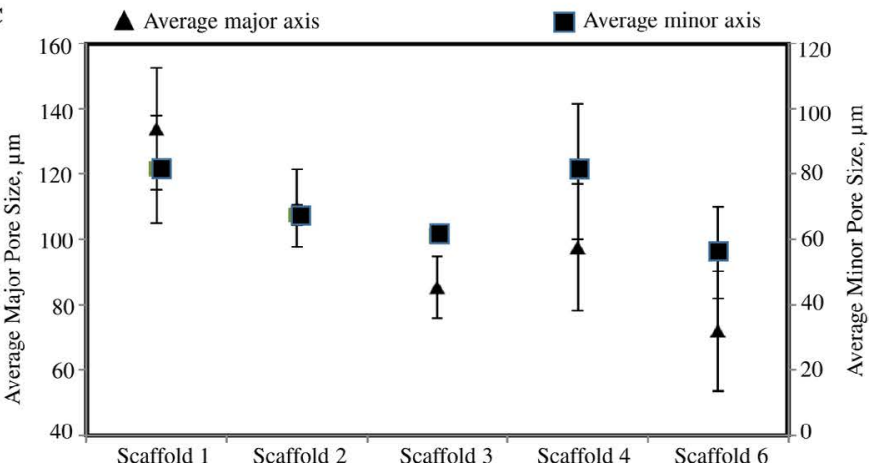

Figure 1: Characterization of the 3D scaffolds. 
Citation: Subramanian R, Bhowmick R, Gappa-Fahlenkamp H (2017) Design of a Novel Method for the Spatial Distribution of Cells within a Porous Scaffold for Tissue Engineering Applications. J Tissue Sci Eng 8: 201. doi: 10.4172/2157-7552.1000201

concentration: Scaffold 1 had the maximum pore size $(132 \pm 18 \mu \mathrm{m})$, while Scaffold 6 had the minimum $(80 \pm 18 \mu \mathrm{m})$. Scaffold 4 had a mean major pore size of $98 \mu \mathrm{m} \pm 19$ and a thickness of $400 \mu \mathrm{m}$. Since this scaffold met the set criteria for the desired scaffold properties, and was durable during handling, it was characterized further. The aspect ratio and roundness of Scaffold 4 was calculated to be 1.23 and 0.83 , respectively.

Figure 1 Characterization of the 3D scaffolds. Scaffolds with varying concentrations of collagen and chitosan (noted in Table 1) were prepared, as stated in Materials and Methods. Scanning electron microscopy at $15 \mathrm{kV}$ with $70 \mathrm{x}$ magnification was used to study the (A) morphology of the scaffolds. Scaffold numbers are noted in inset. Electron micrographs were analyzed with ImageJ software to determine the (B) thickness and (C) pore size of the scaffolds. Note: Scaffold 5 had very few pores, and was thus not included in the thickness and pore size studies.

Porosity and swelling behavior: The porosity of Scaffold 4 was determined using Equation 1. The porosity was measured to be 70.3 $\pm 4.3 \%$. For the calibrated area, approximately 100 pores/section was measured using ImageJ software. The distribution of the pores across three sections of the same scaffold (bottom, middle and top) was consistent with low variability. The mean pore area was around $1000 \mu \mathrm{m}^{2}$.

Most hydrogels, such as collagen and chitosan, swell readily in biological fluids [18]. During swelling, the increase in pore size facilitates cells to attach and penetrate into the scaffold [19]. The swelling behavior of Scaffold 4 was determined using Equation 2. The maximum swelling capacity of our chitosan-collagen scaffolds in medium M199 was $15.91 \pm 1.1$ times the dry weight. The equilibrium was attained in one hour. Therefore, based on the desired thickness, pore size and porosity, Scaffold 4 was chosen for our cell seeding experiments.

\section{Cell morphology within the scaffold}

As a first step to understand the efficacy of our system, we observed the morphology of the cells seeded on the scaffold. When cells are cultured as monolayers, cellular orientation is restricted to the XY plane, while a 3D culture system provides an added third dimension for the cells to orientate. Figure 2 shows a section of the scaffold with the nuclei (A, stained in blue with DAPI) and cytoplasms (B, stained in red with CellTracker Red) $24 \mathrm{~h}$ after seeding. As shown in Figure 2D, the cells attach to the interconnected pore structures (highlighted in Figure 2C) in the scaffold. The uniform cellular distribution in the scaffolds could be due to the establishment of a more physiological cellular network provided by the pore structure. Previous results have also shown that cells cultured in 3D scaffolds develop more in vivo like morphology [3] (Figure 2). Morphology of fibroblasts attached to the 3D scaffolds. CellTracker Red-labeled fibroblasts were seeded on 3D scaffolds as mentioned in Materials and Methods. Cells were counterstained with DAPI and images were captured at $24 \mathrm{~h}$ post-seeding. (A) DAPI stained nuclei; (B), CellTracker Red stained live cells; (C), image of scaffold under white light with highlighted pore; and (D) merged image of A, $\mathrm{B}$ and $\mathrm{C}$.
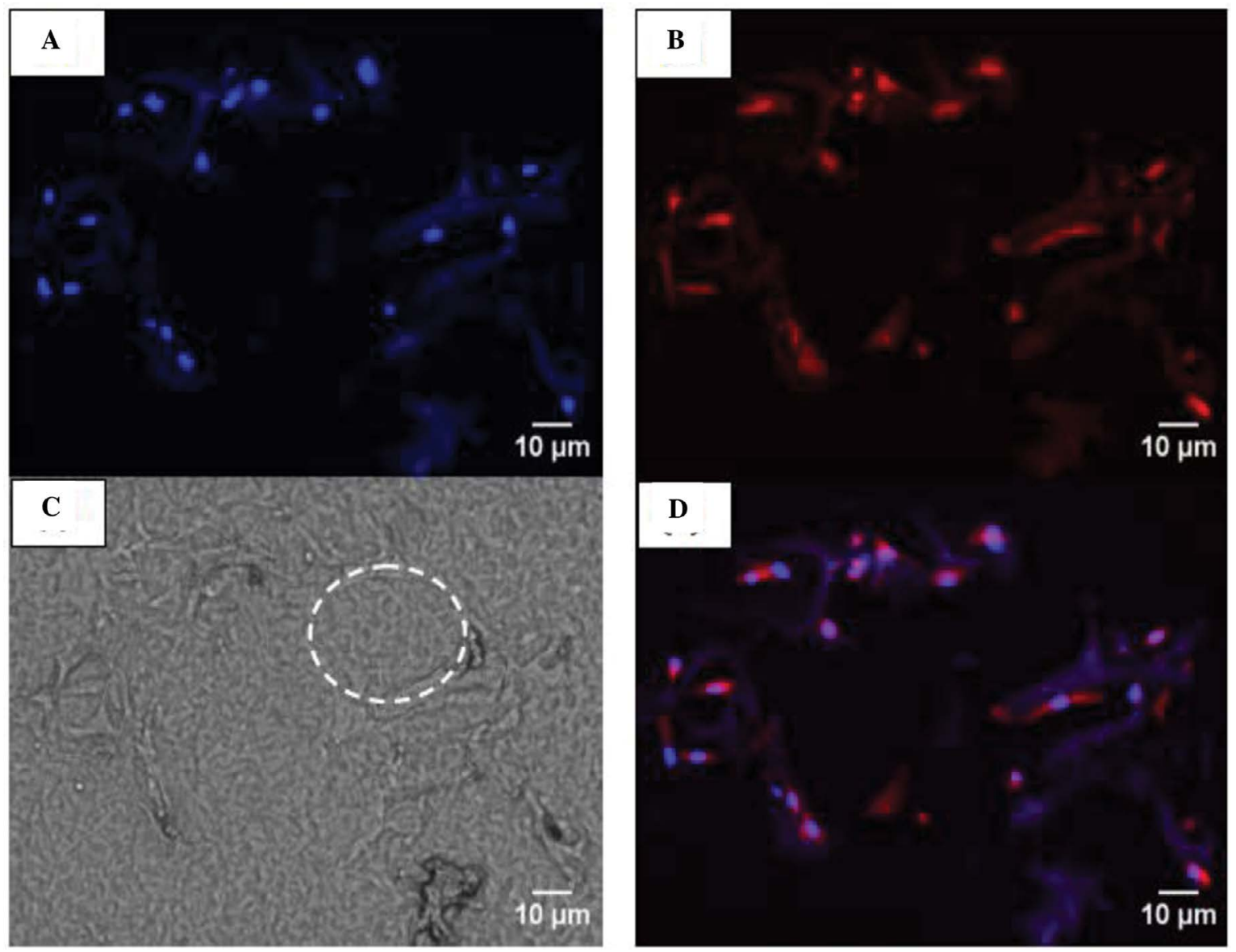

Figure 2: Morphology of fibroblasts attached to the 3D scaffolds. 


\section{Cell seeding efficiency}

An optimal seeding method should result in a high seeding efficiency of cells within the scaffold. To compare the initial cell attachment among the different Seeding Methods (elaborated in Table 2); CellTracker Red-labeled cells were counted by microscopy at $24 \mathrm{~h}$ post-seeding. Figure 3 show that all the 3D scaffolds recorded high cell attachment. In methods where cells were not seeded using the collagen seeding solution, higher centrifugal forces resulted in higher seeding efficiency (Figure 3, compare Seeding Methods 1 and 4, also Table 2). Figure 3 also showed that for methods using similar concentrations of collagen, higher centrifugal forces increased the cell seeding efficiency (compare Seeding Methods 2 and 5; and Methods 3 and 6, also Table 2). Previous reports have also shown that dynamic seeding methods result in a wide range of seeding efficiency depending on cell types (43\% for hepatocytes to $90 \%$ for chondrocytes) [12]. On the other hand, as shown in Figure 3 , the effect of collagen on cell seeding efficiency was less clear. At low centrifugation speeds (1200 rpm), lower concentration of the collagen gel did not improve the seeding efficiency; however, the higher concentration of the collagen gel resulted in higher cell attachment (compare Seeding Methods 1, 2 and 3, also Table 2). Interestingly, at higher centrifugation speeds $(2200 \mathrm{rpm})$, the concentration of the collagen gel did not have an effect on the cell seeding efficiency (compare Seeding Methods 4, 5 and 6, also Table 2).

Cell seeding efficiency and proliferation within the 3D scaffold (Figure 3). CellTracker Red-labeled fibroblasts were seeded on scaffolds according to the Seeding Methods (elaborated in Table 2). Numbers of cells were counted at $24 \mathrm{~h}$ to calculate the cell seeding efficiency. Cell proliferation was determined by calculating the percentage change in the number of cells between 24 and $72 \mathrm{~h}$ post-seeding.

\section{Cell proliferation}

An ideal cell seeding method should also lead to cell proliferation within the scaffold. To investigate cell proliferation within the scaffolds, CellTracker Red-labeled cells in the scaffold were counted by microscopy at $72 \mathrm{~h}$ post-seeding and compared to initial cell counts at $24 \mathrm{~h}$ post-seeding (Figure 3). Our results showed that in Seeding Method 0, where cells were seeded without the collagen solution or centrifugation, the number of cells decreased by $23 \%$ after 72 $\mathrm{h}$ (Figure 3). Seeding Methods that did not seed cells in the collagen solution (Seeding Methods 1 and 4, also see Table 2), also showed little change or a decrease in cell numbers. On the other hand, the Seeding Methods 2, 3, both seeded at low centrifugation speeds and using a collagen solution, showed significant cell proliferation within the scaffold at $72 \mathrm{~h}$ post-seeding, with $132 \%$ and $84 \%$ increase in cell numbers, respectively (Figure 3). At high centrifugation speed, there was an increase in cell numbers for cells seeded in low concentration of the collagen solution, but a decrease in cell numbers when a high concentration of collagen seeding solution was used (compare Seeding Methods 5 and 6, Table 2). The results indicated that both collagen concentration and centrifugal force affected cell proliferation within our 3D scaffold. Among the seeding methods included in our study (elaborated in Table 2), Seeding Method 3, with a combination of high collagen concentration $(2 \mathrm{mg} / \mathrm{ml})$ and low centrifugation speed $(1200$ $\mathrm{rpm}$ ) resulted in optimal cell attachment and proliferation, with the maximum number of viable cells after $72 \mathrm{~h}$ of seeding (Figure 3 ).

\section{Cell distribution ( $24 \mathrm{~h}$ post-seeding)}

We investigated the effect of collagen concentration and centrifugal force on cell distribution along the $\mathrm{Z}$-axis as well as in the $\mathrm{XY}$ plane of the scaffolds at $24 \mathrm{~h}$ post-seeding.

Along the Z-axis: An ideal seeding method would lead to a uniform distribution of cells along the Z-axis of the scaffold. To study the cell distribution along the Z-axis, scaffolds were sectioned and CellTracker Red-labeled cells within the scaffold were counted by microscopy. Figure 4 shows the percentage of cells distributed in the Top, Middle and Bottom sections of the scaffolds for each Seeding Method (elaborated in Table 2). Equal percentages for all three sections would indicate an even distribution of cells along the Z-axis of the scaffold. In Seeding Method 0, the majority of the cells were distributed on the Top surface of the scaffold, with low cell penetration $24 \mathrm{~h}$ after seeding (Figure 4A), indicating that without centrifugation, a majority of the cells remain near the top of the scaffold. When scaffolds were centrifuged at 1200 or $2200 \mathrm{rpm}(259 \times \mathrm{g}$, or $840 \times \mathrm{g}$, respectively) in the absence of collagen (Seeding Methods 1 and 4), a majority of the cells settled to the bottom of the scaffold (Figure 4A), suggesting that

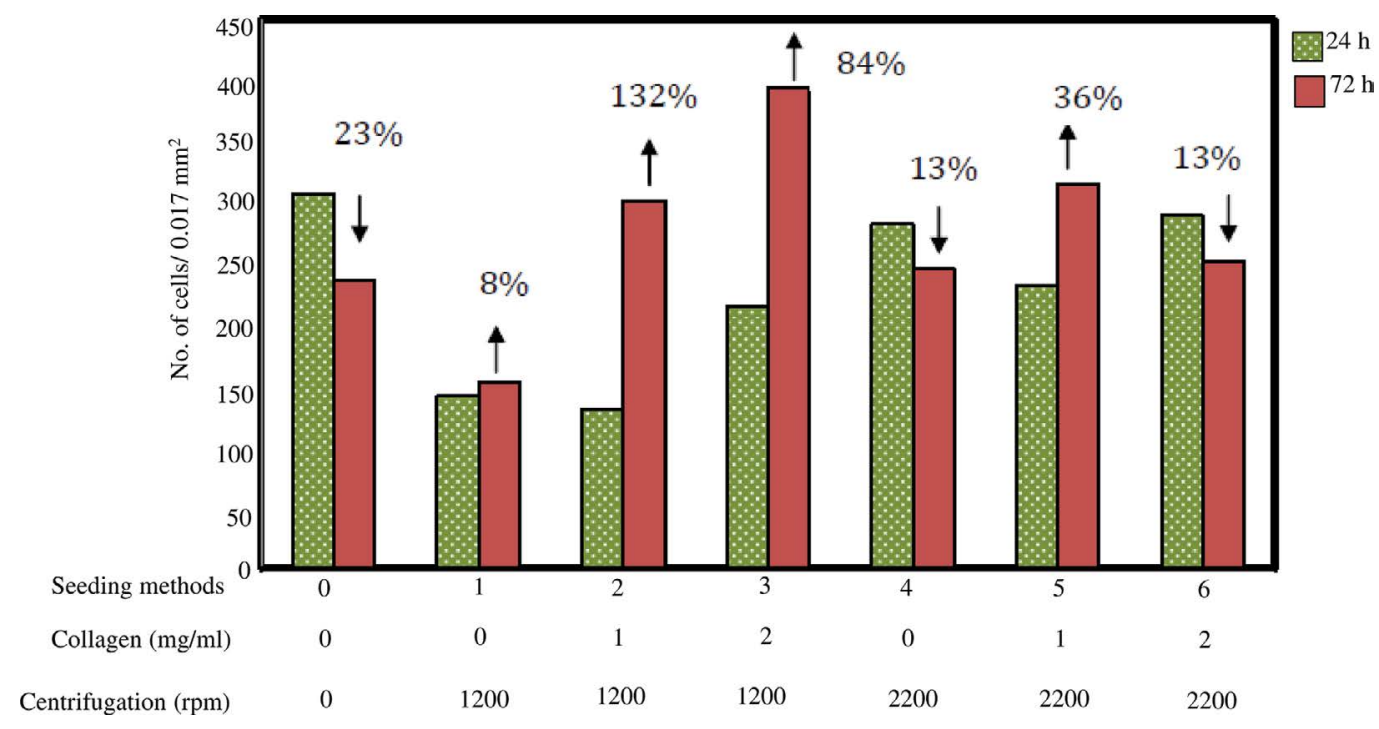

Figure 3: CellTracker Red-labeled cells in the scaffold were counted by microscopy at $72 \mathrm{~h}$ post-seeding and compared to initial cell counts at $24 \mathrm{~h}$ post-seeding 
without collagen the centrifugal force drives the cells to the bottom of the scaffold. Seeding Methods 2 and 3, where cells were suspended in $1 \mathrm{mg} / \mathrm{ml}$ and $2 \mathrm{mg} / \mathrm{ml}$ collagen, respectively, and centrifuged at 1200 rpm $(259 \times \mathrm{g})$, showed a descending order of cell distribution with a majority of cells remaining in the top half of the scaffold (Figure 4A). Seeding Methods 5 and 6, which had 1 and $2 \mathrm{mg} / \mathrm{ml}$ collagen solution, respectively, and was centrifuged at $2200 \mathrm{rpm}(840 \times \mathrm{g})$, showed a more uniform distribution of cells (Figure 4A).

Cell distribution along the $\mathrm{Z}$-axis and in the $\mathrm{XY}$ plane at $24 \mathrm{~h}$ post seeding (Figure 4). CellTracker Red-labeled fibroblasts were seeded on the scaffolds according to the Seeding Methods (elaborated in Table 2) and fixed at $24 \mathrm{~h}$ post-seeding. Scaffolds were sectioned along the thickness and counter stained with DAPI. Images from the Top, Middle and Bottom of the scaffold were captured at 200x and analyzed using ImageJ software. (A), Cell distribution along the Z-axis. (B), Cell distribution along the XY plane for the Top, Middle and Bottom sections of each scaffold. Images were captured from five fields per section. Distribution of cells is denoted with color codes. Red indicates maximum cell clustering and indigo denotes minimum cell clustering.

In the XY plane: The distribution of cells in the XY plane (for each of the Top, Middle and Bottom sections) for the different Seeding Methods is shown in Figure 4B. CellTracker Red-labeled cells were counted within five regions for each section. An equal percentage of cells for all five regions would indicate a uniform distribution of cells. Seeding Method 0 did not have a uniform cell distribution in the XY plane, with cell clustering in all the sections. Our data showed that Seeding Method 3 demonstrated the best distribution of cells at $24 \mathrm{~h}$ (Figure 4B). Seeding Method 6 also achieved good cell distribution in the XY plane, with the Middle and Bottom sections showing better cell distribution compared to the Top. This suggested that high collagen concentration resulted in better cell distribution in the XY plane. Although Seeding Method 5 showed the best distribution of attached cells in the Z-direction at $24 \mathrm{~h}$, this method did not have uniform cell distribution in the XY plane, showing areas of cell clustering (Figure 4B).

\section{Cell distribution ( $72 \mathrm{~h}$ post-seeding)}

Next, we investigated whether the Seeding Methods had an effect on the distribution of cells along the Z-axis as well as in the XY plane of the scaffolds, at longer time points in culture.

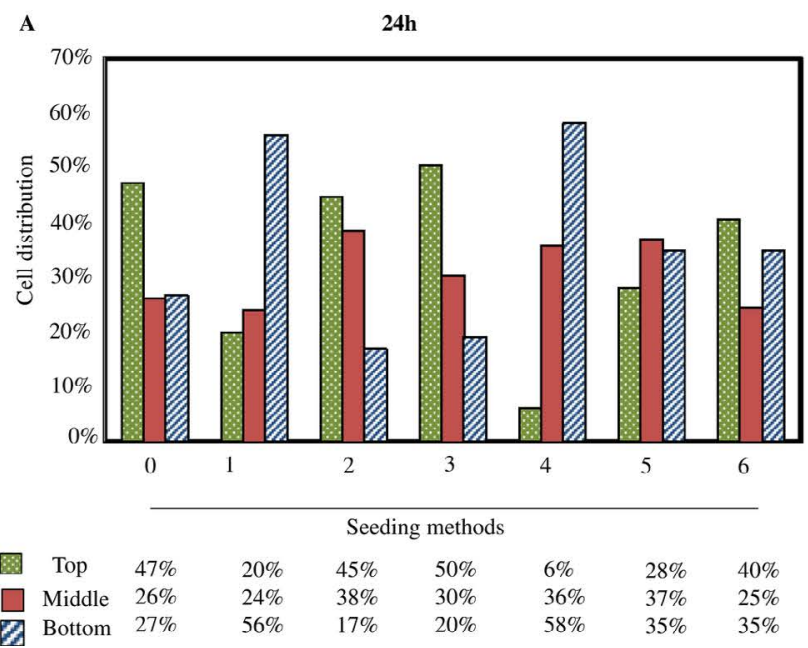

Along the Z-axis: At $72 \mathrm{~h}$ post-seeding, it was clear that collagen concentration and centrifugal forces altered cell distribution within the scaffold (Figure 5A). For Seeding Method 0, where cells were seeded without collagen solution and centrifugation, most of the cells remained near the Top, as shown for $24 \mathrm{~h}$ post-seeding. For Seeding Methods 1 and 4 , where the cells were seeded without collagen, most of the cells remained in the Bottom section of the scaffold, as shown previously at $24 \mathrm{~h}$ post-seeding. However, for Seeding Methods 2 and 3, where cells were seeded with collagen at a low centrifugation speed $(1200 \mathrm{rpm})$, the cell distribution shifted from most of the cells near the Top to most in either the Middle or Bottom sections (Figure 5A). This is in agreement with previous reports which have separately shown that collagen viscosity favors cellular distribution; and centrifugation significantly increases seeding efficiency in PGA scaffolds [20,21]. Although Seeding Methods 5 and 6 resulted in good cell distribution at $24 \mathrm{~h}$ post-seeding, the distributions shifted with more cells near the Top or the Bottom of the scaffold at $72 \mathrm{~h}$ post-seeding, respectively.

Cell distribution along the $\mathrm{Z}$-axis and in the $\mathrm{XY}$ plane at $72 \mathrm{~h}$ post seeding (Figure 5). CellTracker Red-labeled fibroblasts were seeded on the scaffolds according to the Seeding Methods (elaborated in Table 2) and fixed at $72 \mathrm{~h}$ post-seeding. Scaffolds were sectioned along the thickness and counter stained with DAPI. Images from the Top, Middle and Bottom of the scaffold were captured at 200x and analyzed using ImageJ software. (A), Cell distribution along the Z-axis. (B), Cell distribution along the XY plane for the Top, Middle and Bottom sections of each scaffold. Images were captured from five fields per section. Distributions of cells are denoted with color codes. Red indicates maximum cell clustering and indigo denotes minimum cell clustering.

In the XY plane: Similar to $24 \mathrm{~h}$ post-seeding, Seeding Method 0 did not have a uniform cell distribution in the XY plane, with cell clustering in the Middle and Bottom sections. At $72 \mathrm{~h}$ post-seeding, the Seeding Methods 1 through 3 showed similar distribution of cells in the XY plane across all three sections (Figure 5B), indicating that the concentration of the collagen seeding solution was not important for cell distribution along the XY plane. However, at $72 \mathrm{~h}$ post-seeding, higher centrifugal forces resulted in less uniform cell distribution in the XY plane (see Seeding Methods 4 through 6, Figure 5B).

B 24h

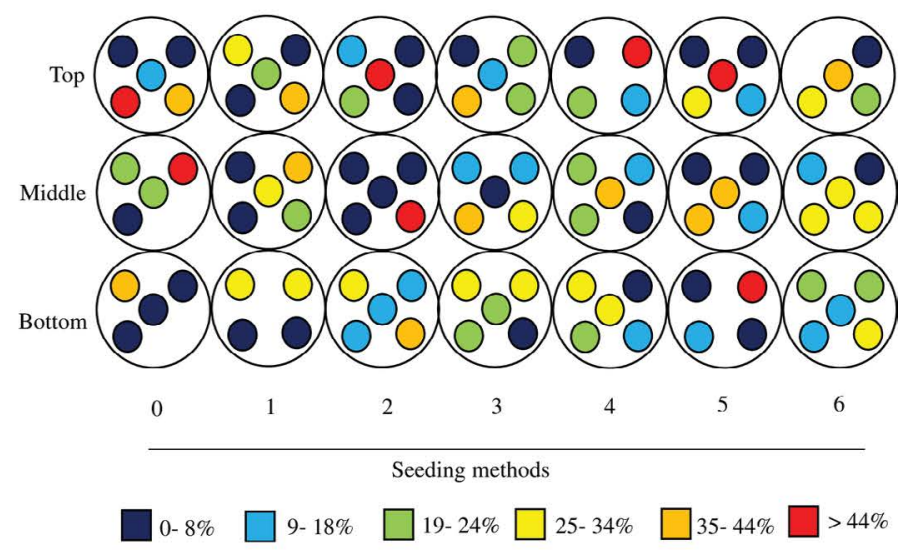

Figure 4: Cell distribution along the Z-axis and in the $\mathrm{XY}$ plane at $24 \mathrm{~h}$ post seeding 
Citation: Subramanian R, Bhowmick R, Gappa-Fahlenkamp H (2017) Design of a Novel Method for the Spatial Distribution of Cells within a Porous Scaffold for Tissue Engineering Applications. J Tissue Sci Eng 8: 201. doi: 10.4172/2157-7552.1000201

Page 7 of 8

Determining the optimum cell seeding method: In order to determine the optimal seeding method that leads to our desired conditions, we ranked the methods based on the following six responses: seeding efficiency, cell proliferation, distribution along the $\mathrm{Z}$ axis after 24 and $72 \mathrm{~h}$, distribution along the $\mathrm{XY}$ plane after 24 and $72 \mathrm{~h}$. Each Seeding Method was ranked 0 through 6, with 0 as the best and 6 as the worst. Seeding efficiency was ranked based on the total number of cells in each scaffold after $24 \mathrm{~h}$. Cell proliferation was ranked based on the total number of cells in each scaffold after $72 \mathrm{~h}$. The distribution of cells along the $\mathrm{Z}$-axis after 24 and $72 \mathrm{~h}$ was ranked based on the deviation from $33.3 \%$ of cells in the Top, Middle, and Bottom sections. The distribution of cells along the XY plane after 24 and $72 \mathrm{~h}$ was ranked based on the deviation from $20 \%$ of cells for each of the five areas counted for each of the Top, Middle and Bottom sections.

Among the seeding methods tested, Seeding Method 0, where cells were seeded without the collagen solution or centrifugation, showed the highest seeding efficiency (Table 3). However, this method showed poor cell proliferation and distribution (Table 3 and Figure 3 ), indicating that dynamic seeding methods with or without collagen were favorable for our 3D scaffolds. Of the dynamic seeding methods (Seeding Methods 1 through 6), Seeding Method 2 showed good cell distribution along both the XY plane and $\mathrm{Z}$-axis at $72 \mathrm{~h}$ post-seeding, but showed very low cell seeding efficiency (Table 3). On the other hand, Seeding Method 6, with high collagen concentration and centrifugation force, showed the best seeding efficiency among the dynamic methods, as well as cell distribution at $24 \mathrm{~h}$ post-seeding, but showed poor cell proliferation and distribution at $72 \mathrm{~h}$ post-seeding (Table 3). Thus, based on the conditions tested in this study, Seeding Method 3 (total score 11), where cells were seeded in a $2 \mathrm{mg} / \mathrm{ml}$ collagen solution and at a centrifugation speed of $1200 \mathrm{rpm}(259 \times \mathrm{g})$, was the optimum seeding method (Table 3 and Figure 3). Even though this seeding method did not show high seeding efficiency and cell distribution in the Z-axis at $24 \mathrm{~h}$ post-seeding, it showed high cell proliferation and distribution at $72 \mathrm{~h}$ post-seeding (Table 3 ).

\section{Conclusion}

This study developed (1) a porous, 3D scaffold with properties for optimal cell seeding; and (2) a new, dynamic method for cell seeding within this scaffold, using a collagen seeding solution and centrifugal force. We tested several cell seeding methods in this study and ranked them for cell seeding efficiency, cell proliferation, cell distribution along the $\mathrm{Z}$ axis after 24 and $72 \mathrm{~h}$, and cell distribution along the XY plane after 24 and $72 \mathrm{~h}$. Based on these rankings, the seeding method with the $2 \mathrm{mg} / \mathrm{ml}$ collagen seeding solution and a centrifugation speed of $259 \mathrm{xg}$ proved to be the optimal seeding method (refer to Table 3 and Figure 3 ). As tissue engineering is increasingly used to generate skin, bones and other organs by using biodegradable scaffolds [22,23], the seeding methods described in this study will prove to be important for seeding cells within such structures.

\section{Ethics Statement}

All experiments included in this study have been performed as per the institutional ethical committee approvals, wherever applicable.
A
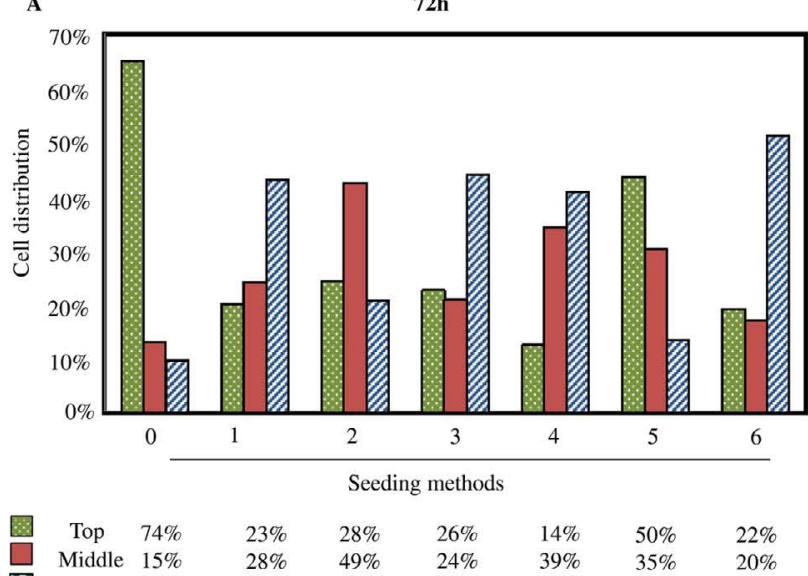

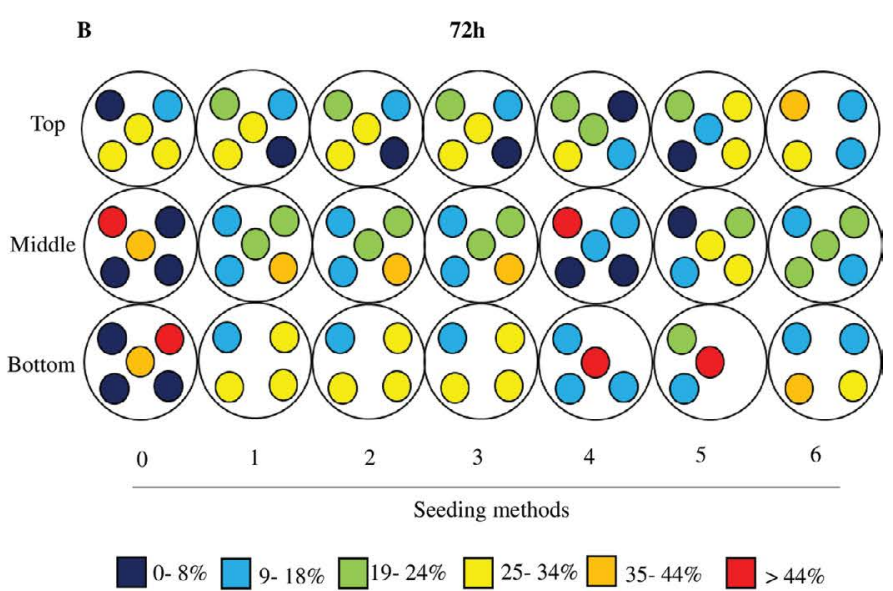

Figure 5: Cell distribution along the Z-axis and in the XY plane at $72 \mathrm{~h}$ post seeding

\begin{tabular}{|c|c|c|c|c|c|c|c|c|c|}
\hline $\begin{array}{l}\text { Seeding } \\
\text { Method }\end{array}$ & $\begin{array}{l}\text { Collagen Conc. } \\
(\mathrm{mg} / \mathrm{ml})\end{array}$ & $\begin{array}{l}\text { Centrifugation } \\
\text { Speed (rpm) }\end{array}$ & $\begin{array}{c}\text { Seeding } \\
\text { Efficiency }(24 \mathrm{~h})\end{array}$ & $\begin{array}{c}\text { Cell } \\
\text { Proliferation } \\
(72 \mathrm{~h})\end{array}$ & $\begin{array}{c}\text { Cell Distribution } \\
\text { Z Direction } \\
(24 \mathrm{~h})\end{array}$ & $\begin{array}{l}\text { Cell Distribution } \\
\text { XY Plane (24h) }\end{array}$ & $\begin{array}{c}\text { Cell Distribution } \\
\text { Z Direction } \\
(72 \mathrm{~h})\end{array}$ & $\begin{array}{c}\text { Cell Distribution } \\
\text { XY Plane (72h) }\end{array}$ & Total \\
\hline 0 & 0 & 0 & 0 & 5 & 2 & 6 & 6 & 6 & 25 \\
\hline 1 & 0 & $1200(259 \times g)$ & 5 & 6 & 5 & 4 & 1 & 1 & 22 \\
\hline 2 & 1 & $1200(259 \times g)$ & 6 & 2 & 3 & 3 & 0 & 1 & 15 \\
\hline 3 & 2 & $1200(259 \times g)$ & 4 & 0 & 4 & 0 & 2 & 1 & 11 \\
\hline 4 & 0 & $2200(840 \times g)$ & 2 & 3 & 6 & 2 & 4 & 3 & 20 \\
\hline 5 & 1 & $2200(840 \times g)$ & 3 & 1 & 0 & 5 & 3 & 5 & 17 \\
\hline 6 & 2 & $2200(840 \times g)$ & 1 & 4 & 1 & 1 & 5 & 4 & 16 \\
\hline
\end{tabular}

Table 3: Ranking of seeding methods based on optimal cell seeding parameters. Each method is ranked 0 through 6 , with 0 as best and 6 as worst. 
Citation: Subramanian R, Bhowmick R, Gappa-Fahlenkamp H (2017) Design of a Novel Method for the Spatial Distribution of Cells within a Porous Scaffold for Tissue Engineering Applications. J Tissue Sci Eng 8: 201. doi: 10.4172/2157-7552.1000201

\section{References}

1. Pampaloni F, Reynaud EG, Stelzer EH (2007) The third dimension bridges the gap between cell culture and live tissue. Nat Rev Mol Cell Biol 8: 839-845.

2. Caron MM, Emans PJ, Coolsen MM, Voss L, Surtel DA, Cremers A, et al. (2012) Redifferentiation of dedifferentiated human articular chondrocytes: comparison of 2D and 3D cultures. Osteoarthritis Cartilage 20: 1170-1178

3. Carterson AJ, Höner zu Bentrup K, Ott CM, Clarke MS, Pierson DL, et al. (2005) A549 lung epithelial cells grown as three-dimensional aggregates: Alternative tissue culture model for Pseudomonas aeruginosa pathogenesis. Infect Immun 73: $1129-1140$

4. Knight E, Przyborski S (2015) Advances in 3D cell culture technologies enabling tissue-like structures to be created in vitro. J Anat 227: 746-756.

5. Badylak SF, Taylor D, Uygun K (2011) Whole-organ tissue engineering: Decellularization and recellularization of three-dimensional matrix scaffolds. Annu Rev Biomed Eng 13: 27-53.

6. Loh QL, Choong C (2013) Three-dimensional scaffolds for tissue engineering applications: Role of porosity and pore size. Tissue Eng Part B Rev 19: 485-502.

7. Daneshmandi S, Dibazar SP, Fateh S (2016) Effects of 3-dimensional culture conditions (collagen-chitosan nano-scaffolds) on maturation of dendritic cells and their capacity to interact with T-lymphocytes. J Immunotoxicol 13: 235-242.

8. Ye K, Felimban R, Traianedes K, Moulton SE, Wallace GG, et al. (2014) Chondrogenesis of infrapatellar fat pad derived adipose stem cells in 3D printed chitosan scaffold. PLoS ONE. 9: e99410.

9. Mahmoud AA, Salama AH (2016) Norfloxacin-loaded collagen/chitosan scaffolds for skin reconstruction: Preparation, evaluation and in vivo wound healing assessment. Eur J Pharm Sci 83: 155-165.

10. Wais U, Jackson AW, Zuo Y, Xiang Y, He T, et al. (2016) Drug nanoparticles by emulsion-freeze-drying via the employment of branched block copolymer nanoparticles. J Control Release 222: 141-150.

11. Dar A1, Shachar M, Leor J, Cohen S (2002) Optimization of cardiac cell seeding and distribution in 3D porous alginate scaffolds. Biotechnol Bioeng 80: 305-312.
12. Ng R, Gurm JS, Yang ST (2010) Centrifugal seeding of mammalian cells in nonwoven fibrous matrices. Biotechnol Prog 26: 239-245.

13. Chen P, Marsilio E, Goldstein RH, Yannas IV, Spector M (2005) Formation of lung alveolar-like structures in collagen-glycosaminoglycan scaffolds in vitro. Tissue Eng 11: 1436-1448.

14. Zhang Y, Cheng X, Wang J, Wang Y, Shi B, et al. (2006) Novel chitosan/collagen scaffold containing transforming growth factor-beta1 DNA for periodontal tissue engineering. Biochem Biophys Res Commun 344: 362-369.

15. Chen RH, Tsaih ML (1998) Effect of temperature on the intrinsic viscosity and conformation of chitosans in dilute $\mathrm{HCl}$ solution. Int J Biol Macromol 23: 135-141.

16. Chung YC, Kuo CL, Chen CC (2005) Preparation and important functional properties of water-soluble chitosan produced through Maillard reaction. Bioresour Technol 96: 1473-1482.

17. Desbrieres J (2002) Viscosity of semiflexible chitosan solutions: influence of concentration, temperature and role of intermolecular interactions. Biomacromolecules. 3: 342-349.

18. Suri S, Schmidt CE (2009) Photopatterned collagen-hyaluronic acid interpenetrating polymer network hydrogels. Acta Biomaterialia 5: 2385-2397.

19. Li Z, Ramay HR, Hauch KD, Xiao D, Zhang M (2005) Chitosan-alginate hybrid scaffolds for bone tissue engineering. Biomaterials 26: 3919-3928.

20. Godbey WT, Hindy SB, Sherman ME, Atala A (2004 )A novel use of centrifugal force for cell seeding into porous scaffolds. Biomaterials 25: 2799-2805.

21. Novak T, Voytik-Harbin SL, Neu CP (2015) Cell encapsulation in a magnetically aligned collagen-GAG copolymer microenvironment. Acta Biomater 11: 274-282.

22. Vapniarsky N, Arzi B, Hu JC, Nolta JA, Athanasiou KA (2015) Concise review: Human dermis as an autologous source of stem cells for tissue engineering and regenerative medicine. Stem Cells Transl Med 4: 1187-1198.

23. Liu Y, Chan JK, Teoh SH (2015) Review of vascularised bone tissue-engineering strategies with a focus on co-culture systems. J Tissue Eng Regen Med 9: 85-105. 